2021, Volume 16, ATEE 2020 - Winter Conference. Teacher Education for Promoting WellBeing in School. Suceava, 2020, pages: 418-429|

https://doi.org/10.18662/lumproc/atee2020/29

\section{Main Principles of Using Audiovisual Method in Teaching the Native Language to Children of Pre- School Age in the Ukrainian Diaspora of The USA and Canada}

Iryna RUDNYTSKAYURIICHUK 1

${ }^{1}$ Yuriy Fedkovych Chernivtsi National University, Chernivtsi, Ukraine, irynarudnitska@ukr.net
Abstract: In the national educational system of the Ukrainian diaspora of the USA and Canada the pre-school period covers the first stages of extra-familiar education, where establishing of child's consciousness and connecting to spiritual values of the Ukrainian nation are taking place. Efficiency of this process depends on multiple factors. A significant role among them is played by didactic provision of educational-instructional process in pre-school educational institutions of various kinds whose main aim is to form national consciousness of the pupils through acquiring the Ukrainian language, as well as mastering contents of Ukrainian Studies subjects.

Pedagogues at Ukerainian pre-school institutions in diaspora conditions clearly understand that the task of bringing up a child before the age of 6 implies providing them with various, beneficial for growing and useful for them, qualities. That is why teachers contribute to children acquiring such knowledge, abilities and skills which would help them to successfully prepare for elementary school in the future.

Since the main task of Ukrainian pre-school education lies in development of a child's personality by means of Ukrainian Culture studies, a pedagogue (teacher) has to know Ukrainian and all subjects well.

Keywords: children, national education, pre-school, ukrainian diaspora, visual-audial method

How to cite: Rudnytska-Yuriichuk, I. (2021). Main Principles of Using Audiovisual Method in Teaching the Native Language to Children of Pre-School Age in the Ukrainian Diaspora of The USA and Canada. In O. Clipa (vol. ed.), Lumen Proceedings: Vol. 16. ATEE 2020 - Winter Conference.

Teacher Education for Promoting Well-Being in School. Suceava, 2020 (pp. 418-429). Iasi, Romania: LUMEN Publishing House. https://doi.org/10.18662/lumproc/atee2020/29 


\section{Introduction}

In spite of present essential researches in the area of teaching children the Ukrainian language, questions which would elucidate peculiarities of using audiovisual method for studying the native language by children of pre-school age in the western diaspora are still being not answered. Analysis of didactic provision of pre-school education and upbringing of foreign Ukrainians are further perspective directions of research of the offered topic.

The aim of the research lies in analyzing peculiarities of teaching the Ukrainian language to children of pre-school age in educational institutions of the Ukrainian diaspora with the use of audiovisual method.

We consider it crucial to point out a series of three study books by Sofiya Vasylyshyn "See. Listen. Speak", which is based on the audiovisual method and aimed at beginner's level.

Another principal position of S. Vasylyshyn as a pedagogue and a study book author deserves to be mentioned. The experienced methodologist emphasizes it is not needed to teach grammar to young kids since they acquire the language in a natural way, though hearing, they perceive automatically gender, number, case conjugations, as well as other main laws of the language. She believes that it is not an easy thing to do and requires extreme patience because one needs to repeat same sentences many times, use various means and methods in order to consolidate the acquired knowledge.

It should be stated that the material presented in the study book and its didactic background give a possibility to diversify children's cognitive activity, ensure their intellectual, physical, moral and aesthetic development, form collaboration skills in pairs and groups, acquire practical skills of using the Ukrainian language in different life situations etc.

While the problem of formation of interest among children of Ukrainian origin to studying the mother tongue is being topical, pedagogues have been looking for effective ways to solve it for decades. Since play is a leading type of educational activity at pre-school and before-school age, experienced pre-school teachers and teachers at native language schools in 
the USA and Canada have been using play methods and means in language teaching.

\section{Research questions/Aims of the research}

The issue of studying the native language in the Ukrainian diaspora of the USA and Canada has been researched in their works by foreign and Ukrainian country study scientists - Borys Azhniuk, Boryslav-N. Bilash, Yosyf Dachkevych, Bohdan Zaklynskyy, Yar Slavutych; peculiarities of teaching children the Ukrainian language have been elucidated by Ivanna Zelska, Stefaniya Mahus, Henrikha Miz', Bohdana Monchak, Nadiya Pikas, Ivan Rusnak, Lesia Khraplyva-Shchur etc.

\section{Research method}

- methods of analysis,

- synthesis,

- systematization and generalization of scientific literature on the researched problem

- audiovisual method.

\section{Discussion}

Since play is a leading type of educational activity at pre-school and before-school age, experienced pre-school teachers and teachers at native language schools in the USA and Canada have been using play methods and means in language teaching. The outcome of their work has become corresponding work books published in different countries where the Ukrainians lived and native language education system was applied which contributed to formation of their national self-consciousness and preservation of ethnic-cultural identity.

It is worth emphasizing that in the teaching of the Ukrainian language, preschool teachers often used games, entertainment, Ukrainian folk tales, legends, entertainment, poems, songs and fables as effective means for ensuring the educational process. They believed that these works 
developed an emotional mood in children, and the activity interactive form gave them the opportunity to better study a new language.

We consider this approach to be quite natural and expedient, because at that time Ukrainian children who had very little or no knowledge of their native language came to Ukrainian kindergartens in the US and Canadian diaspora. Therefore, their education focused on mastering oral speech, and songs, games, and poetry were effective way.

The visual and auditory techniques were recognized as the leading Ukrainian language teaching in Canada in the mid-1970s, so scholars and educators focused their creative research on this area of language didactics.

Textbooks by S. Vasylyshyn are intended for the use in the preparatory class. They are well illustrated; contain auditory and visual material, which study requires high activity not only from the teacher but also from students.

S. Vasylyshyn's textbooks are formed on a seasonal and thematic principle and reflect the nature state and human life at a certain time of the year, as well as tell about events and processes, which active participants and creators are the children themselves. We share the opinion of the researcher S. Romanyuk, who considers it quite appropriate, because such an approach naturally introduces the child to a new period of his life i.e. studying in the preschool class of the Ukrainian Saturday school. The textbooks exterior design is also attractive as the plot drawings reproduce the communication of children dressed in embroidered shirts with books.

The first part of the textbook by S. Vasyyshyn "Look, listen, speak. Autumn" (Vasylyshyn, 1973a) runs with a short introductory word by the author, in which the teacher notes that preparatory classes are a positive phenomenon and therefore should be opened at every school, as they are a kind of bridge between preschool and home school and prepare children for reading and writing. At the same time, S. Vasylyshyn emphasizes that her textbook is designed for children who need to be ready for the primer period with the help of the conversational method, since they do not yet write or read in Ukrainian. It can also be used by students in grades 1-2 who are already reading and writing, but they need to improve their speech. At the same time, it supplements the content of reading books and parents who 
teach their children the Ukrainian language can successfully use it at home. The author's valuable input is appropriate methodological advice for teachers on the use of the textbook during classes, considering the age and psychological characteristics of students. The teaching materials are translated into English, but in the main part of the textbook, which is very important for teachers and students, there is not a single English word (it is the principle position of the author), there is no translation dictionary that is traditional for many Ukrainian textbooks in the diaspora. An interesting achievement of the author is the numerous illustrations that reveal the meaning of the words used in the textbooks.

The first lesson according to the textbook by S. Vasylyshyn, in accordance with the author's idea and the logic of the educational process in preschool classes, begins with the teacher's acquaintance with children and takes the form of the following conversation:

-Good morning, children!

-I'm your teacher ...

-My name is...

-Good afternoon, madam...

-Here's a boy.
-What is your name?

-My name is Petro.

-His name is Petro.

-What is his name?

-His name is Petro

For a better understanding of the teacher's conversation content with the children, the textbook contains a graphic drawing of a boy with a caption below i.e. Peter. During the conversation, students involuntarily memorize the names of their partners, as well as learn about the different categories of pronouns, which are presented in the form of a table for children who can already read.

The dialogue also uses personal pronouns, which are presented in the form of a table.

Table 1. Dialogue with personal pronouns

\begin{tabular}{c|c}
\hline I & He \\
\hline You & She \\
\hline Here & Your \\
\hline This & Our \\
\hline How & Who \\
\hline
\end{tabular}

Source: Vasylyshyn, 1973a, p. 1 
It is also worth noting that the textbook is well illustrated. Each picture has a caption. For example: I am Ukrainian (picture of a boy); We are Ukrainians (picture of a group of children in national clothes) (Vasylyshyn, 1973 a, p. 3). It is also important that all the educational material, which is devoted to the acquaintance of the teacher with children and children with each other, as well as pictures for dialogues, are placed on one page. This technique improves their visual perception, helps them to remember better, and develops children's attention and their memory.

According to the visual and auditory method of language learning, all pictures in the textbook are accompanied by conversational exercises and interesting tasks to the proposed texts. Children's educational activities are diversified by games that are used during the acquisition of language material. A positive feature of the textbook by S. Vasylyshyn is also that it offers texts and dialogues of conversations and corresponding illustrations ("We are Ukrainians", "Our Ukrainian school", "Flags", "Ukrainian language", "Family", “Our house", "Our Church", etc.) selected regarding the age characteristics of children. It is also should be paid attention to the new words are presented in the texts sequentially and framed. The textbook introduces young Ukrainians born in the USA and Canada to the spiritual world of their countries of birth and their homeland, breed them love and respect for the Ukrainian language, state symbols, opens to them the world of environment, human relations, relations with nature, etc.

Valuable thing in the didactic system of S. Vasylyshyn's textbook is the presence of tests of different content, which help the teacher to check the level of children's mastery of the language material. In particular, page 10 offers a test to identify their mastery of the lexical meaning of the studied words. Aiming at this, the teacher demonstrates an object or shows pictures depicting various objects, children, animals, things from the everyday use of kids and offers to name them.

The development of coherent speech is facilitated by a variant of the test, which requires answers in full sentences to the question "Where are they going?". Referring the plot drawings, children have to give the correct answer (Vasylyshyn, 1973a, p. 15).

The textbook by S. Vasylyshyn successfully uses the fairy tales texts, in which it is necessary to name the missing word or words depicted in the 
picture, and repeat the whole sentence after the teacher (this can be done by each child individually and all children in together to better remember it). In order to develop children's speech, the teacher asks them, looking at the picture, to tell the whole fairy tale "Hungry Cat" from the beginning, with each pupil saying one sentence in turn. A sample of such text is given below (Vasylyshyn, 1973a, pp. 48-49):

Fig.1. Excerpt from Vasylyshyn, 1973a, pp. 48-49

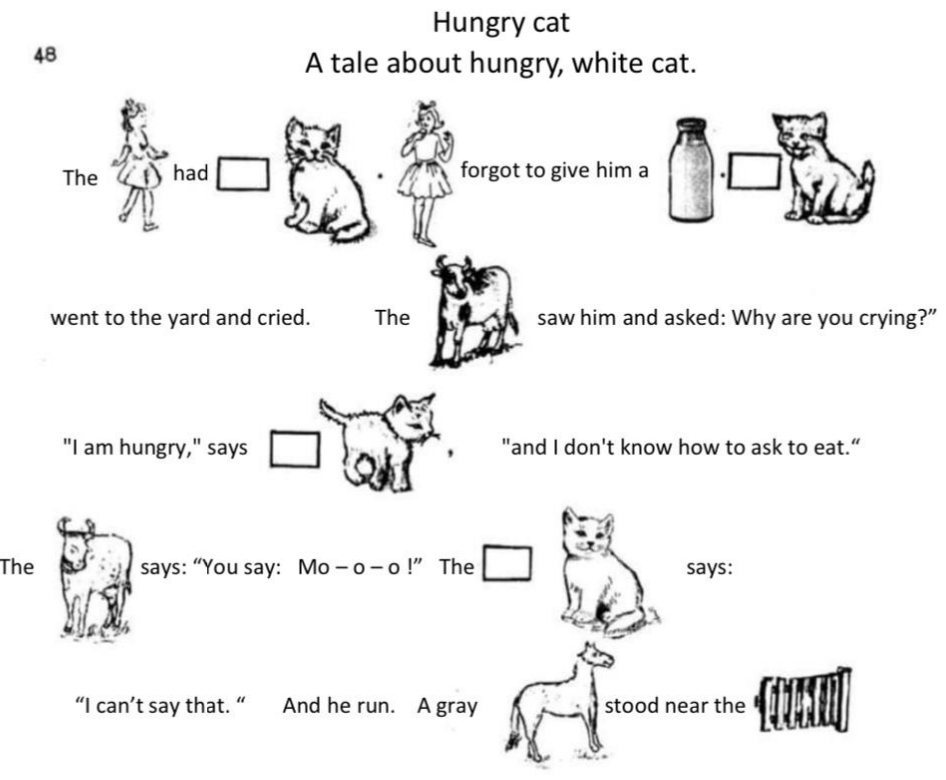

He says, "Why are you crying? "I want to eat and don't know how to say it."

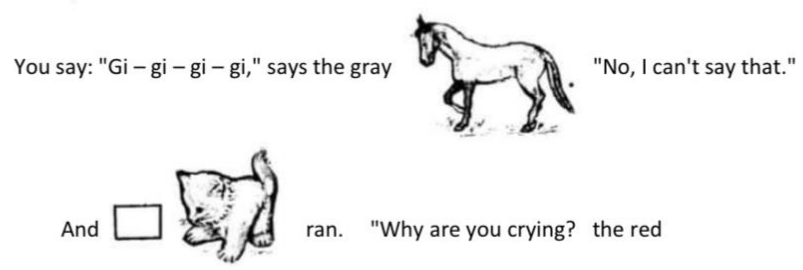


Fig.1. Excerpt from Vasylyshyn, 1973a, pp. $48-49$

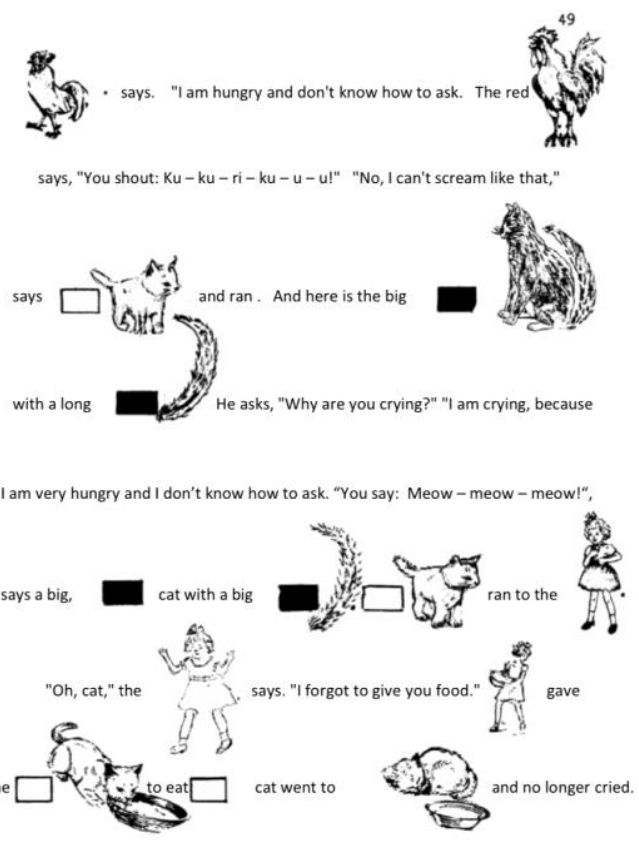

Fig.2. Excerpt from Vasylyshyn, 1973a, pp. 48-49

The textbook concludes with a section called "New Words", which contains all the words from 50 lessons that children must learn according to the first part.

The second part of the S. Vasylyshyn's textbook 'Look, listen, speak. Winter" (Vasylyshyn, 1973b) opens with addressing to teachers and parents and methodical and specific advice on the organization of educational classes (how and what to teach). According to the structure and content, the textbook begins with a picture of winter nature, a house and a snowman with the title "Winter" above it. Accordingly, the first lesson is devoted to winter topics. The proposed text consists of simple sentences about winter and riddles with pictures and thus makes children to be eager to read the following materials about this time of the year. 
In order to complete the task for children "How many words do you remember?", the textbook shows a ladder that a boy climbs, and next to each step there is an image of an object which name needs to be mentioned. The child that cannot remember the corresponding word "falls down." The winner is the child who mentioned the largest number of names and came up with a short sentence with each. In order to test the vocabulary and the ability to express their thoughts orally, students are offered the plot drawings, which they should briefly describe, as well as images of objects, things, products, animals, birds, plants, etc., to which you need to choose words named by the educator (Vasylyshyn, 1973b, p. 3)

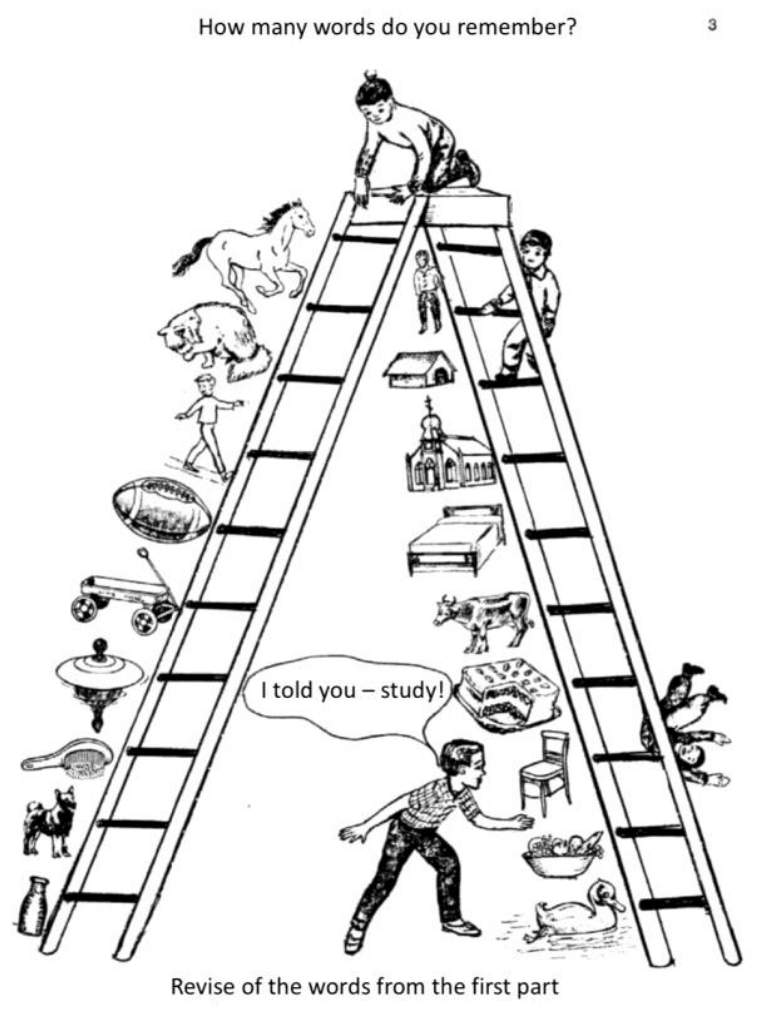

Fig. 3. Excerpt from Vasylyshyn, 1973b, p. 3

The development of speech skills and enrichment of the lexical vocabulary of the Ukrainian language is facilitated by mastering such topics as "Snowflakes", "Snow", "Rabbits in the woods", "Frost", "Clothes for a 
boy", "Clothes for a girl”, "Saint Nicholas", "Christmas Eve", "Holy Supper", "Christmas" etc.

It should be emphasized that the textbook by S. Vasylyshyn not only promotes the acquisition of language material, but also involves children in creative work. When performing exercises and tasks, students must first draw and then cut out the snowflakes depicted in it as a sample, make a snowman, make toys for the Christmas tree, and so on.

The positive thing is that in the S. Vasylyshyn's textbook the educational material is gradually complicated, based on the principles of feasibility, continuity, advanced learning. It provides information about the ordinal number, contains larger texts, poems and songs, didactic games, work with which significantly expands the vocabulary and communication skills of children, enriches their spiritual world, promotes the formation of national consciousness, moral and aesthetic development.

In the third part of S. Vasylyshyn's textbook "Look, listen, speak!" (Vasylyshyn, 1975) contains educational texts on such seasons as spring and summer. As both previous, it starts with general instructions. Addressing the textbook users, the author again emphasizes that "during the initial stage of learning the Ukrainian language, it is important that the child learns to look, or even observe, listen and speak, and reading and writing is a secondary activity in the child's daily activities" (Vasylyshyn, 1975, p. I). In order to facilitate the initial stage of mastering a new language for students of the preparatory class, S. Vasylyshyn included educational material in it, "close to the real daily life of a child, his / her age, environment, interests, etc. This educational material preserves the Ukrainian color and Ukrainian themes" (Vasylyshyn, 1975, p. I). In addition to learning, its use should provide a developmental goal, so "the pupil's activity should be directed so that he learned to see and observe the illustration or written word, so that the pupil tries to draw the learned material. This activity helps the student to systematically develop his/her own visual memory.

Ukrainian studies material is widely presented in S. Vasylyshyn's textbook. After getting acquainted with it (and it is presented in the form of dialogues, texts for reading, poems, songs, riddles, etc.), children will learn about Taras Shevchenko and prepare a concert for his anniversary, Easter holidays, they will prepare a basket and memorize a small poem "Easter", 
which reveals to children the magic of this majestic action. Before Mother's Day, children have the opportunity to learn poems, songs about their mother and take part in a concert on the occasion of this holiday.

The section "Summer" contains a map of Ukraine and a number of dialogues, from which they learn a lot of interesting things about their homeland, and memorize the poem by Yu. Shkrumelyak "Child, you should know!".

The textbook ends, thus and the school year in the preparatory class, with a repetition of the Ukrainian alphabet, which letters are respectively illustrated with drawings and a poem by V. Ninyovskyi "Learning the alphabet."

\section{Results}

The significant features of textbooks for the initial teaching of the Ukrainian language S. Vasylyshyn include:

- successful structuring of an educational material by sections and topics;

- clear sequence of its presentation; availability of practical tasks of a creative nature;

- highlighting in the frame of new words for each topic (not more than 15);

- correspondence of educational material on complexity and volume to age features of pupils;

- dialogic presentation of program material;

- tasks and questions availability for self-examination of the learned material and vocabulary of new words;

- close connection of the content with the real-life needs of students and, accordingly, the ability to use it in different speech situations;

- presence of the Ukrainian studies component aimed at educating children in love for Ukraine, respect for the customs and traditions of the Ukrainian people;

- didactic expediency and functionality of illustrations, their correspondence to the program theme, intelligibility of images to children in the context of the studied subject. 
That is, S. Vasylyshyn's textbooks fully meet the requirements of the visual and auditory method and, with skillful use by the teacher, ensure proper language acquisition by the students of the preparatory class.

\section{Conclusions}

It should be stated that the material presented in the study book and its didactic background give a possibility to diversify children's:

- cognitive activity,

- ensure their intellectual,

- physical,

- moral and aesthetic development,

- form collaboration skills in pairs and groups,

- acquire practical skills of using the Ukrainian language in different life situations etc.

Thus, we can state that a characteristic feature of these manuals is the successful selection of various creative tasks that significantly increase the interest of students in the preparatory class to learn, enhance their cognitive activity, i.e. facilitate understanding and assimilation of educational material and its practical use in speech.

\section{References}

Vasylyshyn, S. (1973a). Dyvys, slukhai, hovory. Pidruchnyk dlia pochatkovo-rozmovnoi kliasy [Look, listen, talk. Tutorial for the elementary class] (Vol. 1, Autumn). Rada Ukrainskoi Shkoly pry UHPTs v Kanadi.

https://diasporiana.org.ua/dityacha-literatura/18849-vasilishin-s-divissluhay-govori-ch-1-osin

Vasylyshyn, S. (1973b). Dyvys, slukhai, hovory. Pidruchnyk dlia pochatkovo-rozmovnoi kliasy [Look, listen, talk. Tutorial for the elementary class] (Vol. 2, Winter). Rada Ukrainskoi Shkoly pry UHPTs v Kanadi.

https://diasporiana.org.ua/dityacha-literatura/18851-vasilishin-s-divissluhay-govori-ch-2-zima

Vasylyshyn, S. (1975). Dyvys, slukhai, hovory. Pidruchnyke dlia pochatkovo-rozmovnoi kliasy [Look, listen, talk. Tutorial for the elementary class] (Vol. 3, Spring and Summer). Rada Ukrainskoi Shkoly pry UHPTs v Kanadi. https://diasporiana.org.ua/dityacha-literatura/18852-vasilishin-s-divissluhay-govori-ch-3-vesna-i-lito 